\title{
An investigation of scaffolding strategies to support structured inquiry language teaching to novice learners in a Primary school setting
}

\author{
Amelie Langdon \\ amelie.langdon@murdoch.edu.au \\ Murdoch University, Australia \\ Jillian M. Pandor \\ jmpcad@rit.edu \\ Rochester Institute of Technology - Dubai, United Arab Emirates
}

\begin{abstract}
It is believed that Inquiry-Based Learning (IBL) affords relevant and meaningful L2 instruction given its contextualised and experiential approach. IBL, which only recently gained popularity in the L2 classroom, strongly differs from that of traditionally didactic methodologies and can present challenges for L2 educators. Research shows that many struggle to adopt a well-rounded inquiry approach and instead tend to over-rely on strategies aiming to make meaning comprehensible to learners, thus neglecting a focus on language form, language use and inquiry skills. This literature review examines current trends in L2 teaching and learning when implementing a structured inquiry approach in the primary school setting and attempts to uncover and evaluate various scaffolding strategies that can be employed to support a more holistic approach to IBL. The language scaffolding practices described in this paper are categorised into four areas of focus: focus on meaning, focus on form, focus on language use, and inquiry skills.
\end{abstract}

Keywords: Inquiry-Based Learning (IBL); Scaffolding, Second Language Acquisition (SLA); Language and Curriculum Integration; Constructivism

\section{SECOND LANGUAGE ACQUISITION}

Over the last few decades, Second Language Acquisition (SLA) researchers have actively sought to comprehend how languages are acquired and learnt (Chomsky, 2006; Krashen, 1982; Vygotsky \& Kozulin, 1986). Over time, an array of sometimes contradicting theories emerged in response to a perceived deficiency of previous approaches. Traditional methods such as the Grammar-Translation Method, with a focus on learning about the language (Bonilla Carvajal, 2013), and the Audiolingual Method, which encouraged memorisation of chunks of languages (Richards \& Rodgers, 2014), were later replaced by the Natural Approach (Terrell, 1977) which emphasised the importance of exposing learners to an extensive amount of comprehensible input in 
the target language (TL) (Krashen \& Terrell, 1983). More recently, the importance attributed to communicative competence and proficiency have given way to 'middle ground approaches' which blend pragmatic and functional knowledge, thus placing language acquisition as a social practice. Researchers such as Cummins (2000), Gibbons (2002), and Ellis and Shintani (2013) strongly support the importance of social interactions and learning in authentic situations as they believe that languages are best acquired in context and through real-life experiences. Although it cannot be said that contemporary theorists have overlooked the cognitive aspects of SLA, current trends advocate for a more balanced focus on form and meaning, a mixture of implicit and explicit teaching, emphasis on extensive and varied language input as well as ample opportunities for output, to name a few of the ten principles of SLA as enunciated by Ellis (2005).

\section{I.1. Constructivism}

In addition to the ever-evolving field of SLA, over the last century, pedagogy has undergone equally tremendous transformation and now favours approaches that promote more student-centred classroom practices (Matamoros-González, Rojas, Romero, Vera-Quiñonez \& Soto, 2017). With the student at the centre of the learning experience, values of mutual respect, growth mind-set, and emotional support are embedded in the learning environment, and thus, guide transformative education in any discipline (Cummins, 2000). At the heart of this revolutionary pedagogical perspective is Constructivism (Piaget, 1952), rooted in the 20th century works of academics from various disciplines including education pioneers Jean Piaget, Lev Vygotsky and Maria Montessori, among others. Constructivism (Piaget, 1952) considers the learner to be an active participant in the discovery and creation of meaning, where learning is embedded in, and occurs from an accumulation of authentic and contextual social interactions experienced by the learner (Lave \& Wenger, 1991; Vygotsky \& Kozulin, 1986). These general pedagogical concepts transfer effortlessly to language learning, therefore, academics in the fields of applied linguistics are encouraging educators to link instructional content to real-world experiences (Ozverir \& Herrington, 2011). 
An investigation of scaffolding strategies to support structured inquiry language teaching to novice learners in a Primary school setting

Such theoretical frameworks of SLA and pedagogy gave rise to Inquiry-Based Learning (IBL) in the language classroom, which offers a framework that allows learners to construct meaning and build knowledge through discovery and investigation. Proponents of IBL argue that children are naturally inquisitive (Schwarzer \& Luke, 2001; Townsend, 2005), and thus inquiry is a natural process of learning (Short, 2009). Although such an approach to teaching languages may appear to be the perfect hybrid of student-centred learning that fosters social interaction, there are several contingencies to its successful implementation which will be explored in further detail in the subsequent sections of this paper.

\section{INQUIRY-BASED LEARNING}

Originally used as a scientific exploration method (Pedaste et al., 2015; Rocard et al., 2007), IBL has proven to be efficient and engaging for all ages and subject matter (Short, 2009; Wells, 1995). However, it presents unique considerations depending on the educational context or discipline at hand (Papaevripidou, Irakleous \& Zacharia, 2017).

IBL encompasses various degrees of facilitator support from high to low levels of guidance, with an inquiry continuum that ranges from 'very structured' with strong teacher guidance, to 'open', student-generated investigation. While open inquiry does offer more voice and choice to students, it is advised to introduce the process gradually and to provide sufficient scaffolding, especially for primary-aged children (Banchi \& Bell, 2008; Killen, 2012).

\section{II.1. Language and inquiry integration: Opportunities and challenges}

The combination of an inquiry-based approach and the use of the TL affords endless possibilities of contextualised scenarios, which as a result are thought to provoke deeper student engagement and motivation as well as more profound opportunities for SLA (Caputo, 2014; Cummins, 2000; Killen, 2012). In line with this notion, Larsen-Freeman (2018, p.64) strongly advocates for a "porous classroom" where the teacher invites a flow of exchange with the world outside the traditional boundaries of the classroom, 
thus exploring and creating language within the context of its natural sociocultural and historical occurrence, not as a series of stand-alone topics or set of grammar rules (Cummins, 2000; Gibbons, 2002; Ozverir \& Herrington, 2011).

In addition to IBL, other discovery methods have served SLA in the past few decades, mainly driven by the need for authentic contexts and the desire to emphasise communicative skills. Such methods, including Content Based Instruction (CBI) (Brinton, Snow \& Wesche, 1989) and Problem Based Learning (PBL) (Boud \& Feletti, 1997), are commonly encountered in the literature. Both operate under the same constructivist paradigm and social constructivist theories as IBL, whereby knowledge is mainly constructed by learners through social interactions, rather than solely via a traditional model of didactic delivery. These approaches have been widely implemented with great success for English Language Learners (ELLs), therefore offering the tangible experiences and relatable contexts sought after in language inquiry interaction (Cummins, 2000; Gibbons, 2002; Walqui, 2006).

In spite of growing evidence to support the benefits of IBL in language classrooms, given the highly contextualised learning environment it affords (Caputo, 2014; Lee, 2014; Wells, 1995), such an approach in an additional language (L2) presents significant challenges for educators and learners alike. This is particularly true among novice language learners of primary school age, which will be the focus of this paper.

Indeed, research in IBL approaches to teaching languages shows that some primary years educators report difficulties in implementing IBL in their L2 classrooms, claiming its incompatibility with novice language learners (Lebreton, 2014; Ledger, Van Vooren, Villaverde, Steffen \& Lai, 2016; Schwarzer \& Luke, 2001). Researchers in the field (Caputo, 2014; Lebreton, 2014; Lee, 2014; Van Vooren, Lai, Ledger, Bueno Villaverde $\&$ Steffen, 2013) have attempted to gain knowledge on this issue and shed light on the following question: How can L2 teachers implement IBL in a language that learners have not yet mastered? To further highlight the relevance of this question, Davidson (2009, p.27) clearly explains that the 'inquiry tools' needed to lead an investigation, such as proficiency in an L2, are still being developed, thus leaving learners faced with a linguistic overload that is likely to cause a major impediment to the proper adoption of IBL in the TL. Inquiring in a language that is still being acquired proves challenging for 
An investigation of scaffolding strategies to support structured inquiry language teaching to novice learners in a Primary school setting

both the learners and the teacher alike, as it forces the inquiry to remain at low-level questioning and thinking (Van Vooren et al., 2013). As a response to such high linguistic demands, learners might resolve themselves to use their mother tongue (L1) to assist them through the inquiry process. This notion is highly debated in the literature, as research shows that some teachers attempt to ban the use of the L1 in their classrooms, considering it to be a practice that is counterproductive to SLA (Dare, 2009), while other studies indicate that the use of the L1 can be a valuable tool to support novice learners in their cognitive development, ensuring a positive psychological outlook towards the L2 (Caputo, 2014; Cummins, 2000; Larsen-Freeman, 2018; Schwarzer \& Luke, 2001).

In addition to the challenge of linguistic load, discovery learning (Bruner, 1961), as a broader pedagogical approach, has also been criticised for putting excessive cognitive pressure on learners (Kirschner, Sweller \& Clark, 2006; Tuovinen \& Sweller, 1999). This argument is based on the claim that minimally guided instructional methods such as IBL, PBL and CBI are less effective for novice learners than more traditional approaches that emphasise direct instruction and strong guidance. According to Kirschner et al. (2006), free exploration and open inquiry put excessive strain on the working memory of the novice learner, who does not yet possess the required prior knowledge to retain new information or apply it in creative ways. However, SLA literature suggests that structured inquiry, or a strongly guided approach to teaching and learning in the TL, can support learners during the acquisition of new knowledge (Caputo, 2014; Killen, 2012; Kirschner et al., 2006).

A structured approach is based on the idea of a zone of proximal development (Vygotsky \& Kozulin, 1986), in which the teacher supports students in bridging a learning gap through scaffolding strategies. It is assumed that such 'structure' in the approach to IBL will be gradually removed in the future when the learner becomes more autonomous and advances in L2 proficiency beyond the novice stages. Therefore, in order to provide tasks that are appropriately challenging, while avoiding cognitive overload or compromising the use of the TL, a high level of teacher support is imperative throughout this approach. This notion is highlighted by Dare (2009), who suggests language teachers should aim to place their pedagogical practices in the 
“developmental zone" (Dare, 2009, p.76), where high-challenge and high-support coexist.

\section{RESEARCH QUESTIONS AND APPROACH TO THE LITERATURE REVIEW}

As presented above, the context of this paper is inscribed in a constructivist approach to L2 teaching, where appropriately structured inquiry and language integration offers valuable learning opportunities. However, some challenges related to adequate linguistic and cognitive loads with respect to novice language learners in an IBL context still need to be addressed in order to ensure the successful implementation of this approach. Therefore, this study aims to explore scaffolding practices found in the literature that can be implemented to support primary-aged novice language learners within a structured inquiry approach based on the recommendations gathered from SLA research, in an attempt to answer the following questions: How can structured inquiry support L2 teachers working with novice learners in primary years curricula that incorporate such methodologies? More precisely, what scaffolding strategies are essential to support language acquisition in a structured inquiry approach?

While the focus of this paper is IBL, it became evident that limited studies have tackled the narrow topic of inquiry-based L2 learning in primary-aged students. Therefore, the search had to expand its scope to include comparable teaching approaches, namely Concept-Based Learning, PBL and other curriculum integration models such as CBI and Content and Language Integrated Learning (CLIL).

Evidence of scaffolding strategies in the literature, where a discovery approach was offered to students, were classified into two main categories: language-specific scaffolding and inquiry-specific scaffolding (see Table 1). In order to organise the language-specific strategies, the framework proposed by Cummins (2000) was adapted to comprise the following three areas of language teaching: focus on meaning, focus on form and focus on use. The focus on meaning category encompasses all strategies and tools that support meaning making and help generate comprehensible input in the TL. Focus on form gathers strategies that teach the language structure and system in a consciousness-raising manner. Focus on use covers strategies that allow learners to use the language in a meaningful and creative way. For the purposes of this study, each area 
An investigation of scaffolding strategies to support structured inquiry language teaching to novice learners in a Primary school setting

of language teaching mentioned above was analysed separately, however in a classroom context they tend to overlap seamlessly.

Inquiry-specific scaffolding strategies were classified according to an adapted version of Wells' (1995, p.244) “Interactive inquiry model of learning and teaching”. This simplified framework consists of three main phases of inquiry: research, interpretation and presentation. The research phase includes all strategies related to initiating interest, formulating questions and explicitly teaching research skills. The interpretation of data stage allows for categorising strategies related to organising and analysing information gathered during the research process. The presentation of findings phase groups teaching strategies related to the ways in which students showcase learning constructed during the process.

Table 1. Evidence of scaffolding strategies present in the literature for a structured language inquiry approach

\begin{tabular}{|c|c|c|c|}
\hline \multicolumn{4}{|c|}{ Structured language inquiry approach } \\
\hline & Language-specific scaffolding & & Inquiry-specific scaffolding \\
\hline ○ & Focus on meaning & o & Research skills \\
\hline ○ & Focus on form & o & Interpretation of data \\
\hline ○ & Focus on use & o & Presentation of findings \\
\hline
\end{tabular}

\section{RESULTS AND DISCUSSION}

As previously mentioned, an adaptation of Cummins' (2000) framework allowed for a categorisation of the type of scaffolding in the following three areas: (a) focus on meaning, (b) focus on form, and (c) focus on use. The data found in the literature are in the form of pedagogical practices as well as recommendations offered by academics in the field of SLA and structured inquiry teaching. A discussion for each category ensues.

\section{IV.1. Focus on meaning}

The literature reveals that in attempts to enrich students' vocabulary and to provide comprehensible input, language educators are using various scaffolding strategies that 
fulfil three main language-related pedagogical purposes: contextualising, bridging and interacting.

\section{IV.1.1. Contextualising}

Contextualising strategies attempt to make meaning clear to students. The literature advises teachers to present their speech in conjunction with non-linguistic tools to provide a rich sensory context with a strong emphasis on visual aids (Dare, 2009; Townsend, 2005; Walqui, 2006). With this purpose in mind, modelling the language through action and dramatisation as well as with visuals, realia, manipulatives and films are commonly employed by language teachers to make the TL accessible to low proficiency learners (Buhrow \& Uoczak García, 2006; Moses, Busetti-Frevert \& Pritchard, 2015; Thomson, 2012; Van Vooren et al., 2013; Zeegers \& McKinnon, 2012). In addition, contextualisation can take its source directly from the content of the curriculum with a CLIL approach. As discussed, language integration has become a trend to promote teaching through the language, rather than about the language; thus making it a popular approach with ELLs in the USA to accelerate the command of academic literacy (Moses et al., 2015; Walqui, 2006; Wells, 1995).

\section{IV.1.2. Bridging}

Generally perceived as good pedagogical practice, bridging strategies are recommended for making connections between background knowledge and new information, and to encourage recall, prediction and inference (Buhrow \& Uoczak García, 2006; Cummins, 2000; Gibbons, 2002; Walqui, 2006). Some evidence of this technique is present in the literature in the form of activities in the Chinese language that involve the exploration and distinction between similar phonological, orthographical or semantic words as a means of highlighting difficulties and ensuring appropriate usage of vocabulary (Lee, 2014). Similarly, in the context of ELLs, Walqui (2006) suggests providing schema building activities in the form of a compare/contrast matrix that offers structured and clear connections between students' prior knowledge and new information. Other researchers enable the creation of links between students' personal interests and 
An investigation of scaffolding strategies to support structured inquiry language teaching to novice learners in a Primary school setting

emotional connections with curriculum content to provide meaningful educative experiences that are relevant to students, and therefore increase individual motivation to learn (Cummins, 2000; Short, 2009). Similarly, when conducted prior to the study of a unit, field trips afford personal experiences and generate enthusiasm about inquiring (Van Vooren et al., 2013). However, it can be argued that it may prove challenging for novice language learners to reach such levels of deep reflection given their age as well as their limited fluency and free expression in the TL. As a means of diminishing such difficulties, front-loading, or pre-teaching new vocabulary/pre-formulating the content that will be covered, is an effective technique for novice learners to access new information and activate prior knowledge (Dare, 2009). Resources such as vocabulary lists, dictionaries, and cue cards are common tools to pre-teach unknown content in order to facilitate comprehension of a text (Moses et al., 2015; Schwarzer \& Luke, 2001; Thomson, 2012; Van Vooren et al., 2013).

\section{IV.1.3. Interacting}

A final category appears in the form of interactional strategies. Classroom interactions including those of teacher-to-student nature, whole class and group discussions, are building blocks of the social constructivist learning theory (Dare, 2009; Schwarzer \& Luke, 2001; Thomson, 2012; Townsend, 2005). During classroom inquiry, questioning, which ultimately drives thinking, is an essential part of IBL (Cummins, 2000; Dare, 2009) and is extensively demonstrated in practice with multiple examples in the literature of whole-class discussion and teacher-led questioning (Buhrow \& Uoczak García, 2006; Moses et al., 2015; Thomson, 2012; Zeegers \& McKinnon, 2012). The quality of teacher-student and student-student interactions is instrumental in ensuring an effective learning environment. The teacher's role in establishing a safe and welcoming classroom culture is an underlying requirement to the success of any of the strategies that are referenced in the literature. Thus, a supportive school context where all learners feel valued and respected as individuals is essential (Cummins, 2000; Gibbons, 2002; Townsend, 2005). It is effectively with the learners' emotional well-being in mind that some teachers are allowing the use of the L1 during L2 lessons (Buhrow \& Uoczak García, 2006; Schwarzer \& Luke, 2001). The process of utilising multiple languages to 
communicate, also called translanguaging ${ }^{\mathrm{i}}$, is increasingly perceived as a meaningmaking strategy by language educators despite generating contentious debates. When students switch languages, not only is comprehension possible, but the learners' individual identity and culture is acknowledged and valued (Cummins, 2000; LarsenFreeman, 2018).

Finally, language educators use corrective feedback during classroom interactions to emphasise appropriate sentence structure and choice of words (Schwarzer \& Luke, 2001; Thomson, 2012; Van Vooren et al., 2013). According to Ellis (2006), corrective feedback enables a focus on syntax through reformulation to enhance meaning as well as reflection on errors, especially in oral interactions.

Considering the variety of 'focus on meaning' strategies encountered in a wide array of action-research papers and linguistic theory, it appears that teachers have a reasonable understanding of how to enhance input for novice language learners by making it more comprehensible. In addition, this varied repertoire may also indicate the belief that offering repeated exposure to the language in the receptive mode is a prerequisite to building meaning (Cummins, 2000; Pritchard, 2009; Schwarzer \& Luke, 2001; Walqui, 2006).

\section{IV.2. Focus on form}

This category focuses on the teaching of formal features and functions of language such as grammar, syntax and orthography (Long, 1988, 1991; Long \& Crookes, 1992). As discussed, while recent SLA research tends to agree on the need to teach grammar, how it is taught is still a controversial topic as contemporary researchers have suggested a more balanced approach (Cummins, 2000; Ellis, 2006). Effectively, it is recommended that teachers continue to give priority to language form, but the approach should be more implicit in nature and based on explorative learning. By raising awareness of the language structure instead of explicitly offering the rule and practicing it through rote exercises, students are able to observe and infer correlation between the meaning and function of certain language structures to thereafter, with appropriate teacher guidance, deduce the grammatical rule in question (Caputo, 2014; Lee, 2014). As a result of this approach, according to Townsend (2005, p.152) "when students increase their 
An investigation of scaffolding strategies to support structured inquiry language teaching to novice learners in a Primary school setting

awareness of the structure and effects of language, they gain proficiency in the use of language". Linking back to the concept of contextualising learning (mentioned in the previous section), research in language teaching shows that enabling connections between content and learners' personal interests also helps to teach grammar in a meaningful way (Gibbons, 2002; Larsen-Freeman, 2015). To illustrate this instructional approach, it is useful to consider Cummins' (2000, p.276) idea of "critical language awareness" which accentuates the need to engage learners in critical inquiry into language form by providing authentic texts with real-life implications or cultural messages that link to students' interests and passions. While many examples can be found that have the potential to promote engagement and motivation to explore forms (Cummins, 2000; Moses et al., 2015, Schwarzer \& Luke, 2001), the literature lacks detail to truly evaluate the effectiveness of such projects, and the degree to which they are conducted in an inquiry-based approach.

It is important to note that form-focused strategies seem underrepresented as a category in comparison to the wider variety of meaning-making strategies introduced above. According to Larsen-Freeman (2015), despite the advice offered by researchers to avoid explicit grammar teaching as an exclusive method, grammar instruction is predominantly taught in a traditional (or didactic) way at the expense of IBL (Lebreton, 2014; Van Vooren et al., 2013). Therefore, it could be hypothesised that progressive language scaffolding strategies, such as raising awareness, only appear sporadically in the literature because they are rarely implemented in practice.

\section{IV.3. Focus on use}

As described by Cummins (2000, p.9), the "focus on use" component of his framework assumes that linguistic production should emphasise the real-life usage of language rather than exclusively its practice; characterised as low-level activities or exercises that involve the repetition of a specific form or function of the language, often deprived of meaningful context. This distinction between practice and use is essential as it has a direct (and generally positive) impact on students' motivation to engage in language production given that true 'usage' of the L2 can only be achieved through learnercentred tasks that are both relevant and challenging (Bunch, 2013). The nature of such 
tasks in the language classroom is described by Ozverir and Herrington (2011) as being ill-defined, close to real-world communicative situations and potentially including various sub-tasks that both scaffold and guide the inquiry process.

In addition, Cummins (2000) emphasises the importance of providing a purpose for language use that affords deeper thinking and questioning to motivate learners to construct and express understanding and meaning. He urges teachers to aspire to educate students, rather than simply teach them, something that can be achieved by offering truly enriching learning experiences rooted in authentic contexts. Field trips, also referenced as a means of contextualising a new language under the heading 'focus on meaning' as mentioned above, even if only possible occasionally, provide rich and authentic opportunities with a genuine purpose for L2 communication. However, as an alternative, authentic tasks designed in the classroom -which entail a level of superficiality because of the contrived environment within the school walls-, still demonstrate a positive impact on the attention span and motivation of young learners who can recognise the applicability of these tasks to real world contexts.

Although sporadic, some evidence of language use classroom strategies embedded in potentially rich communicative opportunities is present in the literature. For instance, tasks requiring students to represent or transform a text into another genre (Walqui, 2006; Zeegers \& McKinnon, 2012) or even the creation of trans-disciplinary texts. While such activities can be engaging and may promote language use (Cummins, 2000; Ntelioglou, Fannin, Montanera \& Cummins, 2014), there is a lack of instructional evidence of adequate inquiry depth. Other instances of language use are offered in the literature such as plays (Ntelioglou et al., 2014; Townsend, 2005) and posters as products of an inquiry project (Buhrow \& Uoczak García, 2006; Moses et al., 2015); however, once again only described briefly. Further information on the approach for each task would be necessary to ensure IBL is properly used in conjunction with the TL, thus presenting the needed conditions for effective language use.

In complement to the tasks evaluated above, other individual scaffolding tools enabling language use are mentioned in the literature. As such, the strategy of shared-writing, by which the learners contribute as a group to the production of a text with the help of the teacher, enable emerging L2 users to be supported in accessing meaningful language 
An investigation of scaffolding strategies to support structured inquiry language teaching to novice learners in a Primary school setting

production (Buhrow \& Uoczak García, 2006; Fullerton et al., 2015; Moses et al., 2015; Ntelioglou et al., 2014). Other tools such as journaling and small group work are reported to be valuable in allowing shy and less confident learners to express their thoughts in the TL in a safe environment (Capitelli, Hooper, Rankin, Austin \& Caven, 2016; Cummins, 2000, Thomson, 2012; Townsend, 2005). For complete language beginners, the use of L1 can also be used to facilitate expression in the most fluent language available, thereby allowing higher-level thinking, which is later translated into the TL to the learner's best ability (Buhrow \& Uoczak García, 2006; Cummins, 2000).

\section{INQUIRY-SPECIFIC SCAFFOLDING STRATEGIES}

According to Killen (2012, p.300), “... [the] primary role [of teachers] should be to help students learn how to think, rather than teaching them how to remember". With this quote as a guide, this next section gathers evidence of scaffolding strategies that support the inquiry process and explicitly teach the skills necessary to successfully conduct IBL in the L2. An adapted version of Wells' (1995) framework was used in efforts to organise the data collected from theoretical academic works and accounts of teachers' pedagogical practice, as described in Table 1.

\section{V.1. Research of empirical data phase}

According to Wells (1995), the research phase of the inquiry cycle should include scaffolding strategies that aim to fulfil three main purposes: to initiate interest, to help in formulating questions, and to teach research skills. The first of these purposes implies offering access to carefully curated, relevant and varied resources. Offering a choice of literary genres, including fiction pieces in addition to informational resources, is recommended to allow the student to consider various standpoints for the same historical event (Short, 2009). Moreover, engagement activities that allow for multiple experiences through exploration of real-world phenomena (Capitelli et al., 2016; Zeegers \& McKinnon, 2012) are powerful tools to support and extend understanding beyond factual resources that are generally prescribed by the curriculum (Short, 2009). In order to generate enthusiasm, such resources and activities should also attempt to 
connect with the learners' prior knowledge and current understanding before being extended.

Once learners have gained familiarity and developed a keen interest in a topic, a natural wondering should occur out of issues discovered in the information-gathering phase. Guidance towards developing a research question is needed at this stage. For this purpose, Short (2009) recommends tools such as "I wonder" journals or classroom charts to follow the process of questioning and reasoning of each student. Other teachers have used modelling and thinking-aloud to generate questions with young emerging L2 learners to help with reasoning in the TL (Moses et al., 2015). The KWL chart -what a student knows [K], wants to know [W], and has learned [L] - is another tool commonly used to track student progress in their investigation and wondering (Moses et al., 2015). At this stage, it is important to note that a structured inquiry approach generally implies that the teacher initiates the topic or question to be explored; therefore, Killen (2012) warns teachers to ensure that the research questions are challenging and engaging for students as well as open for interpretation and adaptation so that they are malleable throughout the inquiry process.

\section{V.2. Interpretation and analysis of data phase}

Once the research stage has generated enough material, learners can start organising and interpreting the data in order to make sense of evidence and attempt to answer the research question. This implies that learners systematically and purposefully collect and record information before coming to conclusions (Wells, 1995). With this purpose in mind, some teacher-researchers report adopting various strategies to keep track of findings. Moses et al. (2015) taught students to record newly learnt information on sticky notes with sentences starting with "I learned" in order to record key information as well as to practice rephrasing relevant content with this sentence starter. Other teachers exploring inquiry-based instruction for ESL, co-create anchor charts with students that enable emerging bilinguals to record their learning and reflect on their thinking. These large classroom displays not only provide a representation of the inquiry pathway but also make an easy reference visual for key vocabulary and meaningful chunks of language which have the added benefit of supporting learners 
An investigation of scaffolding strategies to support structured inquiry language teaching to novice learners in a Primary school setting

with making meaning more comprehensible (Buhrow \& Uoczak García, 2006; Moses et al., 2015).

Although some instances of strategies for organising data are present in the literature, little evidence of strategies enabling an analysis of the data is offered. Instead, the analysis phase is only implicitly mentioned without tangible examples. On the other hand, and in line with socio-constructivist theories, it could be argued that classroom interactions in both L1 and L2 have the potential to facilitate the interpretation and analysis of data phases. Therefore, given the extensive use of class discussion, group and pair work during the inquiry process as presented throughout the reviewed literature (Capitelli et al., 2016; Caputo, 2014; Cummins, 2000; Moses et al., 2015; Wells, 1995; Zeegers \& McKinnon, 2012), it is possible that L2 teachers are heavily relying on this strategy to generate understanding and analysis of data during the inquiry cycle.

\section{V.3. Presentation of findings phase}

This phase includes teaching strategies that support learners in showcasing newly acquired knowledge at the end of the inquiry process. Research shows that presentation skills can be explicitly taught to novice L2 learners through modelling, with an emphasis on common mistakes in efforts to highlight preferred techniques (Moses et al., 2015). Other final products may include brochures, audiotapes, posters or studentdirected lessons to the whole class (Moses et al., 2015; Schwarzer \& Luke, 2001). Surprisingly, the use of technology is only mentioned on rare occasions in the literature (Ntelioglou et al., 2014; Zeegers \& McKinnon, 2012), despite having the potential to be a valuable tool to support language production thanks to its multimodal possibilities to showcase learning (Ntelioglou et al., 2014). Although some examples of what the presentation of findings may look like are offered in the literature, there is very little evidence of how teachers are assisting learners to acquire the needed skills to successfully achieve this goal.

\section{CONCLUSION}


This work aimed to provide a comprehensive literature review of language teaching strategies based in constructivist theory to demonstrate that a structured inquiry approach can support L2 educators in teaching novice language learners in a primary school context. Such evidence was collected from a range of academic research on language acquisition and IBL among primary-aged learners.

In line with current language acquisition research that emphasises the importance of offering extensive comprehensible input (Cummins, 2000; Pritchard, 2009; Swartzer \& Luke, 2001; Walqui, 2006), the above literature review revealed that educators prioritise a wide array of strategies dedicated to meaning-making (i.e. focus on meaning). However, it could be indicative of a tendency towards a more didactic model at the expense of a student-centred IBL approach. Although research supports that learners should also be offered ample opportunities for meaningful language output (i.e. focus on use) as well as being exposed to the language systems through raising awareness (i.e. focus on form) (Cummins, 2000), less evidence of such scaffolding is found in the literature. It was also discovered that few strategies are employed to explicitly teach inquiry skills, especially with respect to the interpretation of data phase. It is unclear whether this lack of information is due to a deficiency of knowledge of inquiry and language integration on behalf of teachers, or whether this topic is still at the early stages of exploration as a field of research; therefore, a more extensive search would be valuable.

Congruent with constructivist ideas, structured L2 inquiry should employ varied scaffolding strategies to equally address language meaning, form and use alongside authentic learning as a means of acquiring the TL. Therefore, the present work may be useful in promoting teachers to rethink L2 pedagogy and ensure that all phases of the inquiry process and all language modes and skills are adequately supported with efficient strategies to yield meaningful learning experiences for students; something that can be achieved through a successful process of structured inquiry.

\footnotetext{
Notes

${ }^{i}$ Defined by Larsen-Freeman (2018) as situations "where students use, rather than exile, their existing language resources in their learning of a new language" (p.61).
} 
An investigation of scaffolding strategies to support structured inquiry language teaching to novice learners in a Primary school setting

\section{REFERENCES}

Banchi, H., \& Bell, R. (2008). The many levels of inquiry. Science and Children, 46(2), $26-29$.

Bonilla Carvajal, C.A. (2013). Grammar-Translation Method: A linguistic historic error of perspective: Origins, dynamics and inconsistencies. Praxis \& Saber, 4(8), $243-263$.

Boud, D., \& Feletti, G. (1997). The challenge of problem-based learning (2nd ed.). London: Routledge.

Brinton, D.M., Snow, M.A., \& Wesche M.B. (1989). Content-based second language instruction. New York: Newbury House.

Bruner, J.S. (1961). The act of discovery. Harvard Educational Review, 31(1), 21-32.

Bunch, G.C. (2013). Pedagogical language knowledge: Preparing mainstream teachers for English learners in the new standards era. Review of Research in Education, 37(1), 298-341. doi: 10.3102/0091732X12461772.

Buhrow, B., \& Upczak García, A. (2006). Ladybugs, tornadoes, and swirling galaxies: English language learners discover their world through inquiry. Portland: Stenhouse Publishers.

Capitelli, S., Hooper, P., Rankin, L., Austin, M., \& Caven, G. (2016). Understanding the Development of a Hybrid Practice of Inquiry-Based Science Instruction and Language Development: A Case Study of One Teacher's Journey Through Reflections on Classroom Practice. Journal of Science Teacher Education, 27(3), 283-302. doi: 10.1007/s10972-016-9460-9.

Caputo, L. (2014). Using Inquiry-Based Learning to Teach Additional Languages in a High School Context. In P. Blessinger and J.M. Carfora (Eds.), Inquiry-Based Learning for the Arts, Humanities, and Social Sciences: A Conceptual and Practical Resource for Educators (pp. 369-391). Bingley: Emerald Group Publishing Limited. 
Chomsky, N. (2006). Language and mind (3rd ed.). New York, NY: Cambridge University Press.

Cummins, J. (2000). Language, power and pedagogy: Bilingual children in the crossfire. Clevedon, England: Multilingual Matters (Bilingual Education and Bilingualism). Retrieved from https://ebookcentral-proquestcom.libproxy.murdoch.edu.au

Dare, B. (2009). English as a Second Language. In S. Davidson and S. Carter (Eds.), Taking the PYP Forward (pp. 74-89). Woodbridge: John Catt Educational Ltd.

Davidson, S. (2009). Communities of Inquiry. In S. Davidson and S. Carter (Eds.), Taking the PYP Forward (pp. 27-42). Woodbridge: John Catt Educational Ltd.

Ellis, R. (2005). Principles of instructed language learning. System, 33(2), 209-224. doi: 10.1016/j.system.2004.12.006

Ellis, R. (2006). Current issues in the teaching of grammar: An SLA perspective. TESOL quarterly, 40(1), 83-107. doi:10.2307/40264512

Ellis, R., \& Shintani, N. (2013). Exploring Language Pedagogy through Second Language Acquisition Research. New York: Routledge.

Fullerton, S. K., McCrea-Andrews, H., \& Robson, K. (2015). Using a Scaffolded MultiComponent Intervention to Support the Reading and Writing Development of English Learners. ie: inquiry in education, 7(1), 1-20.

Gibbons, P. (2002). Learning Language, Learning through Language, and Learning about Language: Developing an Integrated Curriculum. In P. Gibbons (Ed.), Scaffolding Language, Scaffolding Learning: Teaching Second Language, Learners in the Mainstream Classroom (pp. 118-138). Portsmouth: Heinemann.

Killen, R. (2012). Effective teaching strategies: Lessons from research and practice (6th ed.). South Melbourne: Cengage Learning Australia.

Kirschner, P.A., Sweller, J., \& Clark, R.E. (2006). Why Minimal Guidance During Instruction Does Not Work: An Analysis of the Failure of Constructivist, Discovery, Problem-Based, Experiential, and Inquiry-Based 
An investigation of scaffolding strategies to support structured inquiry language teaching to novice learners in a Primary school setting

Teaching. Educational Psychologist, 41(2), 75-86. doi: 10.1207/s15326985ep4102_1

Krashen, S. D. (1982). Principles and practice in second language acquisition. Oxford: Pergamon Press.

Krashen, S. D., \& Terrell, T. D. (1983). The Natural Approach: Language Acquisition in the Classroom. San Francisco: Alemany Press.

Larsen-Freeman, D. (2015). Research into practice: Grammar learning and teaching. Language Teaching, 48(2), 263-280. doi: 10.1017/S0261444814000408

Larsen-Freeman, D. (2018). Looking ahead: Future directions in, and future research into, second language acquisition. Foreign Language Annals, 51(1), 55-72. doi: 10.1111/flan.12314

Lave, J., \& Wenger, E. (1991). Situated Learning: Legitimate Peripheral Participation. Cambridge: Cambridge University Press.

Lebreton, M. (2014). Additional language teaching within the International Baccalaureate Primary Years Programme: A comparative study. Journal of Research in International Education, 13(1), 3-18. doi: $10.1177 / 1475240914521346$

Ledger, S., Van Vooren, C., Villaverde, A. B., Steffen, V., \& Lai, C. (2016). More than a second language: Leadership structure and pedagogic strategies in an Australian International Baccalaureate PYP additional language program. Journal of Second Language Teaching \& Research, 5(1), 6-36.

Lee, H. 2014. "Inquiry-based Teaching in Second and Foreign Language Pedagogy". Journal of Language Teaching and Research, 5(6), 1236-1244. doi: 10.4304/jltr.5.6.1236-1244

Long, M.H. (1988). Instructed Interlanguage Development. In L. Beebe (Ed.) Issues in Second Language Acquisition. New York: Newbury House, 113-141.

Long, M.H. (1991). Focus on Form: A design feature in language teaching methodology. In K. de Bot, R. Ginsberg and C. Kramsch (Eds.), Handbook of 
research on second language acquisition (pp.39-52). Amsterdam: John Benjamins.

Long, M.H. \& Crookes, G. (1992). Three approaches to task-based syllabus design”. TESOL Quarterly, 26, 27-56. doi: 10.2307/3587368

Matamoros-González, J.A., Rojas, M.A., Romero, J.P., Vera-Quiñonez, S., \& Soto, S.T. (2017). English Language Teaching Approaches: A Comparison of the Grammar-Translation, Audiolingual, Communicative, and Natural Approaches. Theory and Practice in Language Studies, 7(11), 965-973. doi: $10.17507 /$ tpls.0711.04

Moses, L., Busetti-Frevert, R., \& Pritchard, R. (2015). Inquiry as ESL: Supporting emerging bilinguals' content and language development. The Reading Teacher, 68(6), 435-447. doi:10.1002/trtr.1333

Ntelioglou, B. Y., Fannin, J., Montanera, M., \& Cummins, J. (2014). A multilingual and multimodal approach to literacy teaching and learning in urban education: a collaborative inquiry project in an inner city elementary school. Frontiers in Psychology, 5, 533. doi: 10.3389/fpsyg.2014.00533

Ozverir, I., \& Herrington, J. (2011). Authentic activities in language learning: Bringing real world relevance to classroom activities. In T. Bastiaens and M. Ebner (Eds.), Proceedings of ED-MEDIA 2011--World Conference on Educational Multimedia, Hypermedia \& Telecommunications (pp. 1423-1428). Lisbon: Association for the Advancement of Computing in Education (AACE).

Papaevripidou, M., Irakleous, M., \& Zacharia, Z. (2017). Using teachers' Inquiryoriented Curriculum Materials as a Means to Examine their Pedagogical Design Capacity and Pedagogical Content Knowledge for Inquiry-based Learning. Science Educational International, 28(4), 271-292.

Pedaste, M., Mäeots, M., Siiman, L.A., de Jong, T., Van Riesen, S.A., Kamp, E.T., \& Tsourlidaki, E. (2015). Phases of inquiry-based learning: Definitions and the inquiry cycle. Educational Research Review, 14, 47-61. doi: 10.1016/j.edurev.2015.02.003 
An investigation of scaffolding strategies to support structured inquiry language teaching to novice learners in a Primary school setting

Piaget, J. (1952). The Origins of Intelligence in Children. New York: International Universities Press.

Pritchard, A. (2009). Ways of Learning: Learning Theories and Learning Styles in the classroom (2nd ed.). Oxon: Routledge.

Richards, J.C., \& Rodgers, T.S. (2014). Approaches and Methods in Language Teaching. Cambridge: Cambridge University Press.

Rocard, M., Csermely, P., Jorde, D., Lenzen, D., Walberg-Henrikson, H., \& Hemmo, V. (2007). Science Education Now: A Renewed Pedagogy for the Future of Europe. Brussels: European Commission (Technical Report No. EUR22845). Retrieved from http://www.ec.europa.eu/ research/sciencesociety/document_library/pdf_06/report-rocardon-science-education_en.pdf

Short, K.G. (2009). Inquiry as a stance on curriculum. In S. Davidson and S. Carter (Eds.), Taking the PYP Forward (pp.11-26). Woodbridge: John Catt Educational Ltd.

Schwarzer, D., \& Luke, C. (2001). Inquiry Cycles in a Whole Language Foreign Language Class: Some Theoretical and Practical Insights. Texas Papers in Foreign Language Education, 6(1), 83-99.

Terrell, T.D. (1977). A Natural Approach to Second Language Acquisition and Learning. Modern Language Journal, 61(7), 325-337. doi: 10.1111/j.15404781.1977.tb05147.x

Thomson, N. (2012). Language Teaching Strategies and Techniques Used to Support Students Learning in a Language other than their Mother Tongue. Kongsberg International School. Retrieved from https://www.ibo.org/contentassets/4ccc99665bc04f3686957ee197c13855/thomp $\underline{\text { son_execsum_8-29-12.pdf }}$

Townsend, J. S. (2005). Language Arts: Explore, Create, Discover Through Inquiry. In R.H. Audet and L.K. Jordan (Eds.), Integrating Inquiry across the Curriculum (pp. 111-136). Thousand Oaks: Corwin Press. 
Tuovinen, J.E., \& Sweller, J. (1999). A comparison of cognitive load associated with discovery learning and worked examples. Journal of Educational Psychology, 91(2), 334-341. 10.1037/0022-0663.91.2.334

Van Vooren, C., Lai, C., Ledger, S., Bueno Villaverde, A., \& Steffen, V. (2013). Additional language teaching and learning in International Baccalaureate Primary Years Program schools. The Hague: International Baccalaureate Organization.

Vygotsky, L.S., \& Kozulin, A. (Ed.) (1986). Thought and Language. Cambridge: MIT Press.

Walqui, A. (2006). Scaffolding Instruction for English Language Learners: A Conceptual Framework. International Journal of Bilingual Education and Bilingualism, 9(2), 159-180. doi: 10.1080/13670050608668639

Wells, G. (1995). Language and the inquiry-oriented curriculum. Curriculum Inquiry, 25(3), 233-269. doi: 10.1080/03626784.1995.11076181

Zeegers, Y., \& McKinnon, H. (2012). 'Does a spider have fur'? Blending primary science and English language learning for ESL students. Teaching Science: The Journal of the Australian Science Teachers Association, 58(4), 7-13.

Received: 09 June 2020

Accepted: 02 December 2020

Cite this article as:

Langdon, A., \& Pandor, J.M. (2020). An investigation of scaffolding strategies to support structured inquiry language teaching to novice learners in a Primary school setting. Language Value, 13 (1), 1-22. Jaume I University ePress: Castelló, Spain. http://www.languagevalue.uji.es.

DOI: http://dx.doi.org/10.6035/LanguageV.2020.13.1

ISSN 1989-7103 